\title{
The Role of Public Spaces in Reviving the Historical Areas: The Case Study of As-Salt City in Jordan
}

\author{
Bushra Zalloom $^{1 *}$, Mohannad Tarrad ${ }^{2}$ \\ ${ }^{1}$ Department of Engineering Technology, School of Architecture, Zarqa University, Zarqa 13132, Jordan \\ ${ }^{2}$ Department of Engineering, School of Architecture, Al-Bayt University, Mafraq 25113, Jordan
}

Corresponding Author Email: bzalloom@zu.edu.jo

https://doi.org/10.18280/ijsdp.150313

Received: 1 September 2019

Accepted: 10 February 2020

\section{Keywords:}

public spaces, historical areas, as-salt city, reviving, heritage buildings, world heritage list

\begin{abstract}
The study aims to clarify the role of public spaces in the revival of historical areas, and to formulate solutions to deal with public spaces in heritage areas. The city of As-Salt in Jordan is the case study; it is selected for its architectural importance nationally and internationally. The city of As-Salt was nominated by the Government of Jordan to be on the World Heritage List of the UNESCO as it has a recognized architectural style that represents the traditional Levant architecture. This study draws the path for decision makers at the As-Salt Development Corporation, the As-Salt municipality, as well as the Ministry of Tourism; it highlights the shortages of the As-salt file that was presented to the UNESCO in 2018. This study proposes novel strategies to help in putting the City in the World Heritage List by considering the role of public spaces in linking the nominated historical buildings.
\end{abstract}

\section{INTRODUCTION}

Jordan has a number of ancient places and heritage buildings that have been studied by many researchers to explore the mechanism of dealing with these heritage sites [1]. A series of conferences were organized by various authorities to preserve historical sites and heritage buildings such as: the first architectural conference entitled "Preserving Architectural Heritage in Jordan and the Arab World" organized by the University of Jordan in cooperation with the Aga Khan Unit in 1993, the Jordanian Architectural Conservation Conference organized by the Ministry of Municipals, and Rural and Environmental Affairs in 1997 and the first Balqa Engineering and Heritage Conference organized by the Jordanian Engineers Association in 2008 [2]. These conferences focused on a range of local projects in Jordan that worked on the rehabilitation of old buildings without attention to the surrounding urban spaces. However, the Jordanian Urban Heritage Law of 2005 emphasized that the urban sites include all the urban fabric, the public squares and the residential neighborhoods that represent the cultural values of residents [2].

Accordingly, this study aims to fulfill the gaps of the previous studies, and focuses on the role of public spaces in reviving the historical areas at As-Salt city in Jordan, and help in adding the city to the World Heritage List of the UNESCO. This study highlights the shortages of the As-salt file that was presented to the UNESCO in 2018, and proposes novel strategies to overcome them by considering the role of public spaces in linking the nominated historical buildings. Accordingly the following topics will be discussed:

- Defining the public space in the city and its main functions

- Reviewing the international strategies for preserving public spaces in historic areas
- $\quad$ The case study of the As-Salt city

\section{METHODOLOGY}

The importance of the public spaces and its role in revving the historical areas was examined through a scientific review to the existing laws and literature to explore the main strategies that are used in preserving the historical sites and then apply them on the historical public spaces in Jordan, specifically in the As-Salt city. After that, to achieve the research aim and to increase the possibility of adding the city of As-Salt to the World Heritage List, a comprehensive review to the As-Salt file, that was presented to the UNESCO in 2018, were made to discover its gaps and overcome them in the future submission.

Finally, a field observation was conducted, from February to May 2019, to explore the most important public spaces that link between the historical buildings, and explore their current role in the city, and their physical characteristics. These public spaces were totally ignored and not mentioned in the As-Salt file in 2018.

\section{DEFINING THE PUBLIC SPACE IN THE CITY AND ITS MAIN FUNCTIONS}

The scholars discussed the concept of the public space and its relation with the surrounding buildings by focusing on the concepts of solid and void. John Simonds (1998) asserted that without the void, the solid will have no value [3]. Thus, the shape, size and quality of the space will have a strong effect on the solid blocks around it. One space serves more than a solid mass and connects them together. This phenomenon can be easily recognized in the evolution of the Islamic 
architecture where the courtyard of the mosque forms the center of the Islamic city planning and positively reflects the concept of economic and social space [4]. The concept of the courtyard has been developed and transformed to form the nucleus of city where the public spaces connect the solid masses or buildings surrounding them and where people easily can meet and socialize.

When defining the space, it is clear that it has no limit and various definitions [5]. Some scholars try to explore the relationship between senses and movement inside the space, which connected with the characteristics of the space and its architectural style [6]. According to them, the user enjoys the movement in a space with composite structure that contains a lot of details and sceneries more than the movement in a simple space that can be understood immediately $[7,8]$. Therefore, the outdoor spaces in the city are categorized into several types:

3-1 Public space: It is the space that is cut off from the natural space. The buildings are arranged to represent the urban identity. There is an important relationship between urban spaces, functions and activities that directly affect the users' enjoyment and reactions to the surrounding environment [9].

3-2 Urban space: It is the confined space or the axis between the various elements, structural or natural ones. These elements help the user to perceive and understand the surrounding environment. The most important element in the urban space is the land that includes the landscape elements such as plants, furniture, fountains, and lightings [7: 56].

3-3 Open Space: A group of non-built and abandoned areas that are used as a buffer zone to breakdown the urban mass and provide natural ventilation and lighting besides preserving the privacy. These areas include parks, squares and public plazas. The open areas are different from the vacant areas, where the latter includes areas for future uses, but not yet exploited [6, 7].

\section{REVIEWING THE INTERNATIONAL STRATEGIES FOR PRESERVING PUBLIC SPACES IN HISTORICAL AREAS}

The developed countries realized the value of preserving the historical areas as a prerequisite for preserving the identity of the society and its important role in cultural communication. The historical areas include the historical buildings and the spaces surrounding them. Moreover, the methods of preserving the historical areas are ranging from the macro level that focuses on the urban squares and its historical buildings to the micro level that focuses on the building's facades $[6,10]$.

Analyzing the strategies used in preserving the historical buildings in developed countries confirms that preservation is not only a matter of conserving the building's condition, but also it is about creating life in the historical public spaces surrounding it [11]. This also includes the identification of the best use and the optimal investment through public participation to transform these areas into an integral part of the urban system in order to create an identical public space that integrates with its surrounding and combines the old features with the modern ones. The Washington Charter [12] for the Conservation of Historic Cities and Areas in 1987 states that "the participation and the involvement of the residents are essential for the success of the conservation programme and should be encouraged", in order to encourage their participation and involvement, a general information programme should be set up for all residents beginning with children in schools [11].

The Washington Charter (1987) recommended a set of principles and methods to preserve historic public spaces, according to them, "in order to be most effective, the conservation of historic towns and other historic urban areas should be an integral part of coherent policies of economic and social development and of urban and regional planning at every level" [12]. The Washington Charter suggested various methods and strategies, it highlighted that the conservation plan should aim at certifying a harmonious relationship between the historic urban areas and the town as a whole. However, before any intervention, existing conditions in the area should be carefully documented.

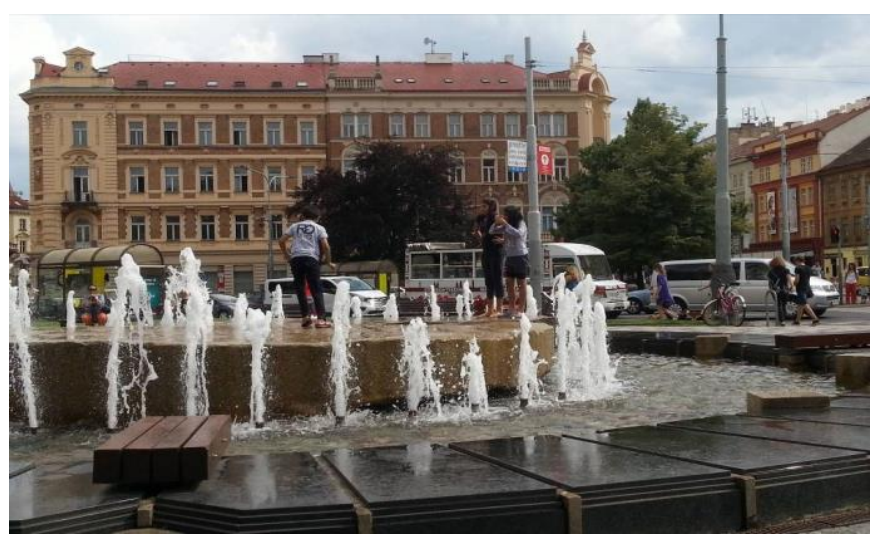

Figure 1. Rehabilitation of the heritage buildings and their adjacent squares in Prague/Czech Republic. Source: the corresponding author, 2018

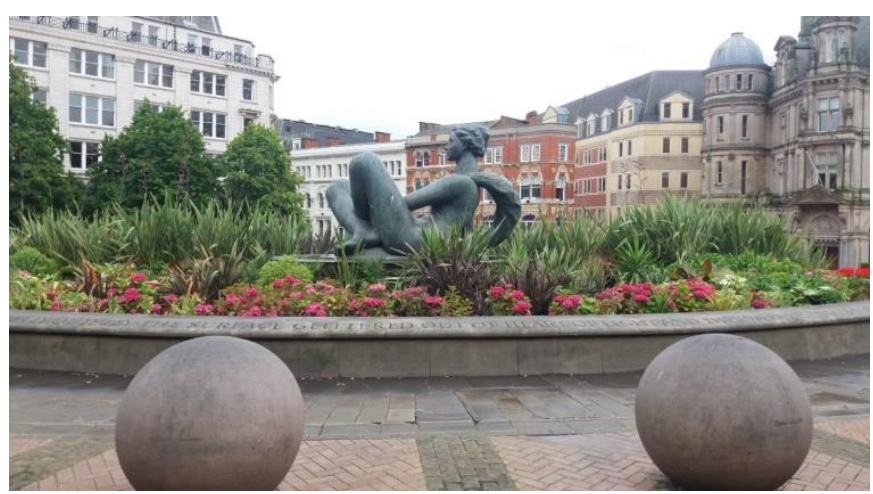

Figure 2. Rehabilitation of the heritage buildings and their adjacent squares in Birmingham/United Kingdom. Source: the corresponding author, 2017

Reviewing the experiences of some European countries in the preservation of heritage buildings shows a clear commitment to rehabilitate and preserve the heritage buildings and its adjacent squares, combining them into one object that is easily recognized and accepted by the users, Figure 1 and Figure 2. Adaptation of these areas to contemporary life requires the careful installation or improvement of public service facilities. The introduction of contemporary elements in harmony with the surroundings should not be discouraged since such features can contribute to the enrichment of an area [13]. Therefore, it is necessary to achieve harmony between the landscape elements, and select them to suit the culture of 
users and then distributed them in a way that makes it easier for them to recognize and accept.

\section{THE CASE STUDY OF THE AS-SALT CITY}

As you walk through the city center, you can trace the richness of the Roman, Mameluke, and Ottoman Empire. During the last fifty years of the Ottoman Empire (1870-1920), the As-Salt region became wealthy through the arrival and settlement of merchants from Nablus, Syria and Egypt who built their fortunes on trade, banking and farming [4, 14]. This new middle class invested in the development of large family mansions, and their prosperity attracted skilled craftsmen. The As-Salt was transformed from a rural settlement into a thriving city, with a significant townscape and an elaborate architecture, reflecting various influences and styles [14]. The city has a mixed Muslim-Christian population and its trading tradition helped create an atmosphere of tolerance and co-existence.

As-Salt began to expand and new construction and architecture sprung. The first modern Church was built, along with the first hospital and school. Shops spread and houses built from yellow stone, that incorporated indigenous and European styles with more than one floor, domed roofs and inner courtyards, some with ceilings painted by Italian artists $[15,16]$. Furthermore, the Islamic inscriptions and arches have added an aesthetic appearance that reflects the originality of the Arab-Islamic art [4]

The historical fabric of the ancient city of As-Salt is characterized by its architectural style, construction materials, and the formation of the infrastructure that reflects the social and economic relations [14-16]. The city location and the hilly topography have affected the overall shape of the city and guided its urban growth [16]. The urban fabric of the mountainous city of As-Salt is rich; the stairs passed down through the hilly topography and connected with the alleys [10], Figure 3.

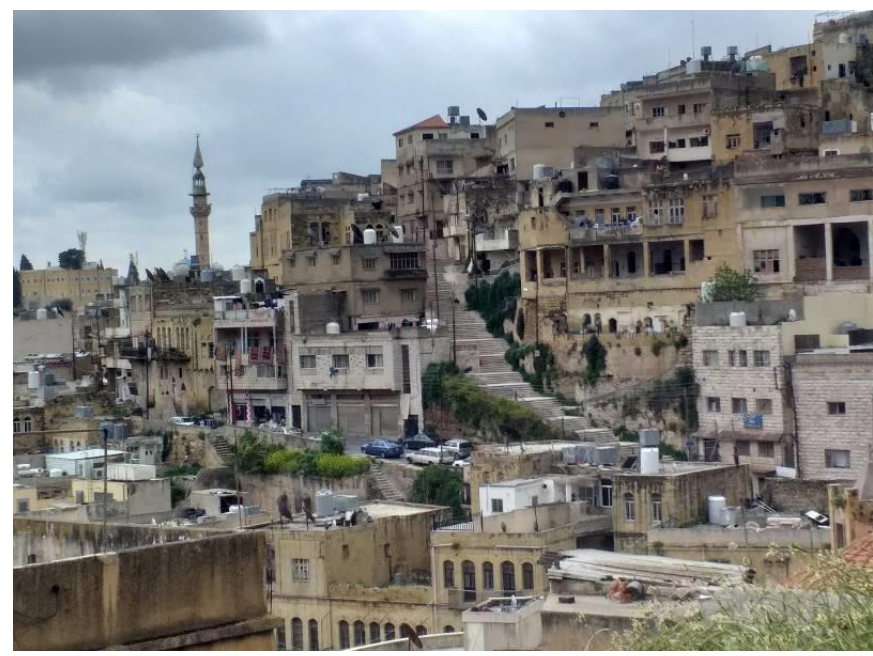

Figure 3. The hilly topography of the As-Salt city. Source: The corresponding author, 2019

The As-Salt is gradually growing; therefore, the pattern of the urban spaces at the city center is similar to the layout of the traditional Islamic city $[15,16]$, where the buildings and the masses are arranged around a central public space. The hardyellow stone is the main construction material that characterized the buildings of the As-Salt. Almatarneh "This natural material that used in construction is generally lower in embodied energy and toxicity than man-made materials. They require less processing and are less damaging to the environment ". [17:107].

\subsection{The city of as-salt on the world heritage list}

The Ministry of Tourism and Antiquities in Jordan documented about nine hundred heritage buildings inside the As-Salt city; it recognized the aesthetic of the ancient city and decided to present its distinctive architectural character to the whole world. The ministry started to revive the old heritage through the restoration of houses, streets and stairs that leading to the old neighborhoods.

The Royal Scientific Study (RSS) conducted a study that documented the heritage buildings in the As-Salt for the first time in 1989 and was funded by the USAID. The study set the ground for developing a comprehensive record of the traditional buildings in As-Salt. It considered the buildings prior to 1950 as heritage ones, accordingly 657 buildings were listed $[1,10]$. One of the restrictions to its implementation was the absence of a national umbrella and appropriate legislation to protect architectural heritage after AD1700, at that time, no GIS data was available for the city. Later, in 2010 the Japan International Corporation Agency (JICA) conducted a survey about the Cultural Resources in As-Salt. A catalogue of 1019 resources was issued for the surveyed resources using the GIS [1].

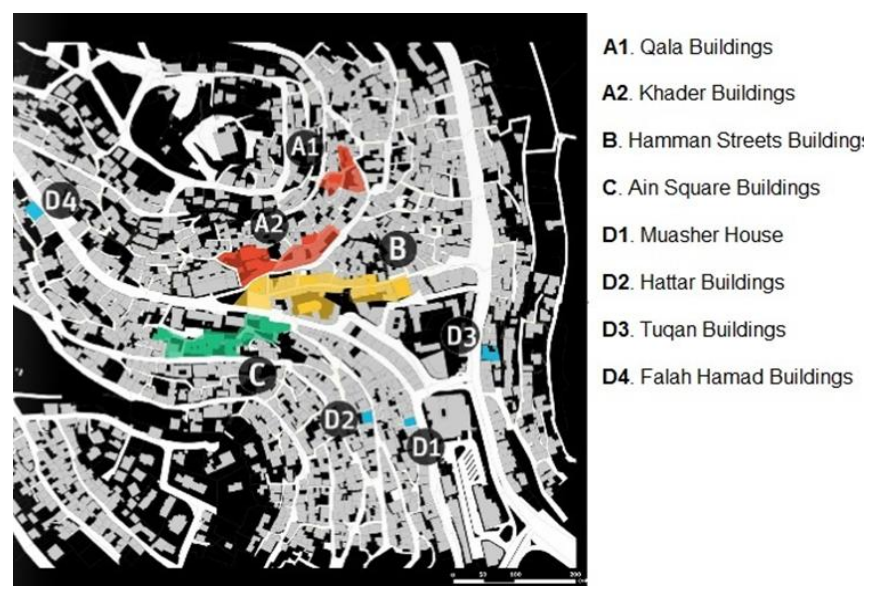

Figure 4. The eight components that contains the nominated buildings. Source: As-Salt Development Corporation, 2019

During the 1990s, the Ministry of Tourism and Antiquities in collaboration with the Municipality of As-Salt and the AsSalt Development Corporation has prepared a file that aims to introduce the city of As-Salt to the World Heritage List. Jordan already counts five places listed as World Heritage Sites, which are Petra, Um Arassas, Wadi Rum, the Baptism Site (Bethany) and Qusseir Amrah. The selected properties in the As-Salt comprised of eight zones that contain the twenty-two best preserved houses built at the historic core of As-Salt around the main square, Sahat Al-Ain, shaping a unique townscape (Figure 4).

The nominated buildings were built in the period of 1865 to 1925; together they represent the original 'Eclectic Arab Architectural Style' of the Levant. The exceptional value of this Arab Eclectic Movement in the History of Art and Architecture is based on its recognizable identity and uniqueness within its cultural setting, and in its capability to 
translate the peaceful coexistence of Muslims and Christians societies [14].

The Eclectic Style has various materials that integrate the traditional style with the modern style creating a precise language that passed through several development stages. The Eclectic architectural school of the As-Salt exhibits a main exchange of human values; being the outcome of a hybridization of architectural styles (a Neo-classic lexicon) integrated in other cities of the Ottoman Empire, and shaped the cityscape of the As-Salt. The association of intangible heritage values to these buildings and the townscape that contains them plays an important role in the readability of the historic fabric of As-Salt. These splendid yellow sandstone buildings incorporate a variety of local and European styles. Typically, they have domed roofs, interior courtyards, and arched windows [17], the most well-known building is the Abu Jaber house (Figure 5), built between 1892 and 1906, and currently used as a museum.

The file of the As-Salt downtown has been inscribed in the Tentative List of UNESCO World Heritage Sites since 2004. The file was submitted to UNESCO and rejected many times in the 1990s, 2004, in 2016, and in 2018. Accordingly, a Road Map was initiated by the UNESCO office in Amman to prepare a practical document outlining the required steps by the Government that leading to a future nomination of the site [18].

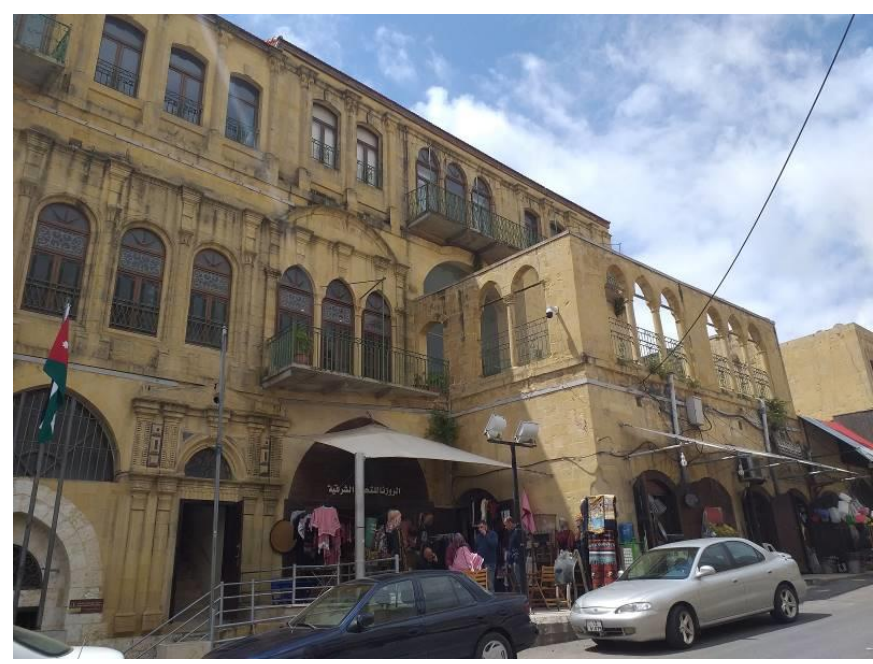

Figure 5. Abu Jaber house presents the architectural style of the city. Source: The corresponding author, 2019

Reviewing the UNESCO report by the authors confirms that the International Council on Monuments and Sites "ICOMOS" has some worries about the capability of the eight components to be understood or read as fragmented parts of a coherent whole [18]. It is obvious that it is unclear to ICOMOS how these isolated components can be understood well separated from a central element that connect them, and how can the visitor appreciate the urban fabric during the late Ottoman period and of the rise of modernity in the Arab world without having a certain core that connects these fragments. Therefore, ICOMOS asserts that an enveloping buffer zone is essential to linking the nominated buildings and integrating them together [18]. ICOMOS records that the nominated buildings is authentic as the architectural forms, styles, designs, decorations and materials reflect the Levant architectural style, however, ICOMOS has some concerns about the urban landscape and the manner that the modern usages will admire the original use of the buildings [18]. Furthermore, ICOMOS states that the authenticity of the building is at risk due to the form of the wider urban landscape, and the fragmented quality of the selected components [18].

\subsection{Reviving the historic public spaces at AS-Salt}

The analyses of the UNESCO report and the studying of the ICOMOS feedback confirm that the refusal of including the city of As-Salt on the World Heritage List is due to nominating and mentioning the architectural importance of many historical buildings at the city without highlighting how these buildings may connect and create a beating heart at the city center or even how they may represent a unique the identity of the As-Salt city, as a result, these buildings were recognized by the UNESCO as fragmented parts. This analysis emphasizes the research importance and reflects the research aims, as the submitted file did not contain comprehensive treatments for the urban landscape and did not mention any of the existing public spaces that played a vital role in reviving the city. Rather, it focused on the architecture of the heritage buildings as fragmented components without paying attention to the public spaces, squares, and corridors that link these buildings.

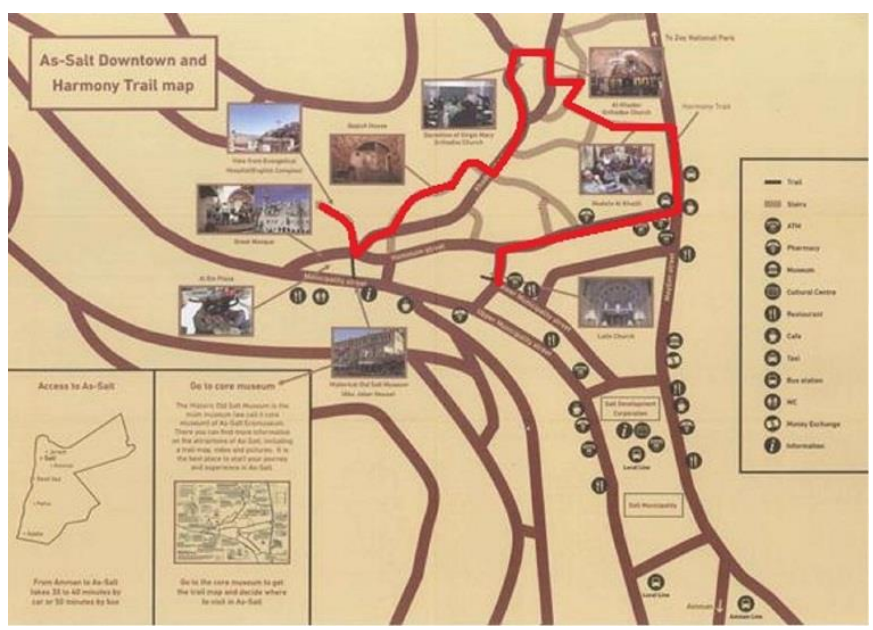

Figure 6. The Harmony Trail shown in red line. Source: AsSalt Development Corporation, 2019

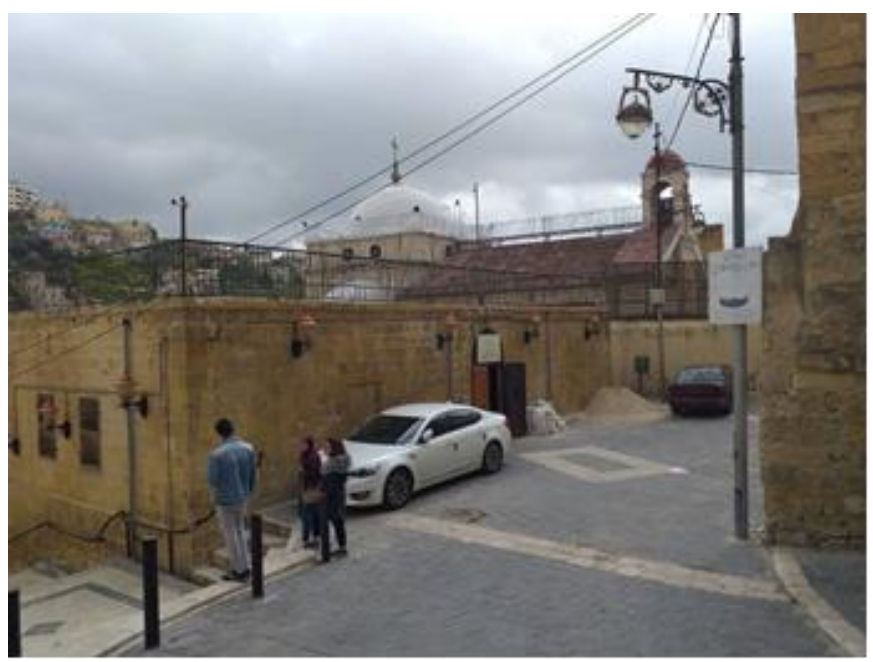

Figure 7. The Church at the Khader Street. Source: The corresponding author, 2019 
In addition, the file submitted to UNESCO did not mention the As-Salt Harmony trail that combines the life style between Muslims and Christians which represents one of the most important tools to link various parts of the nominated buildings at the downtown, specifically at the Qala Buildings, khader buildings, Hamman Street buildings and the Ain Square buildings. This trail consists of a main path of $2 \mathrm{~km}$ and subways of $7 \mathrm{~km}$ (Figure 6). The Harmony trail includes a specific main route through which the visitor moves, starting from the visitors' point at the bus stop, heading towards the Khader Street with its ancient religious history, passing through the saints' tombs and Al-Khader Orthodox Church (Figure 7), to the Hammam Street, which boasts more than 100-year-old shops, traditional heritage cafes towards the Ain square opposite the As-Salt Great Mosque and finally to the As-Salt Museum at the Abu Jaber House. The Harmony trail informs tourists about the aesthetic and architectural details that enable them to discover the history of the city.

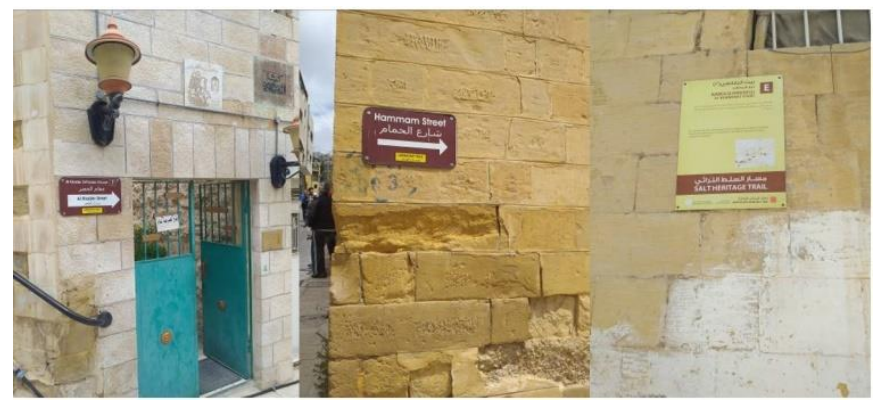

Figure 8. The guidance boards that facilitate pedestrian movement, Source: the corresponding author, 2019

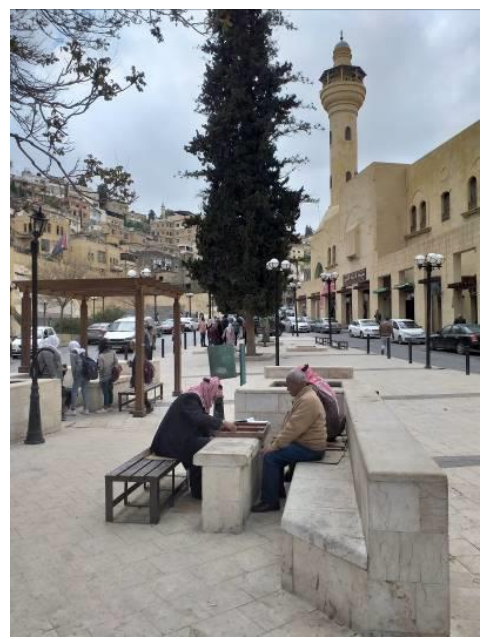

Figure 9. People socialize and play Al-Mungala game at the Ain Square. Source: the corresponding author, 2019

The As-Salt file ignores the importance of the public squares, the paths and the stairs as key elements in linking the city center with its surrounding neighborhoods and in giving the city its unique identity, while different rehabilitation works have been carried out within these spaces to facilitate pedestrian movement, such as the preparation of guidance boards, adding the lighting elements, benches, pergolas, passageways, and other street furniture (Figure 8). The As-Salt file mentions the heritage buildings at the Ain Square and studies their architectural style, but it never highlights the importance of the Ain Square as a beating heart for the city, as a livable space that connects the city center with its neighboring areas, a space where people socialize and elderly sit and practice their favorite hobby when playing the game of Al-Mungala, which came with the Turks more than five hundred years ago (Figure 9).

Additionally, the file lacks the mention of the most important tourist projects that were implemented and constructed in Al Hammam Street, started with the United States Agency for International Development in 1994, followed by the Japanese project in 2004 to complete the development of the rest of the street with the same quality of work and specifications, followed by the Ministry of Tourism and Antiquities project in 2010 to work on cleaning the buildings' fronts and developing the urban facades. All these projects aim at developing this vibrant and essential link while preserving its traditional identity.

The Hammam Street includes shops on the ground floors and apartments on the upper floors, the architectural style of buildings reflects the architecture of 1881-1918, and the structural system in that period is characterized by the existence of arches and one-meter-thick walls. The Hammam Street retains its distinctive traditional heritage where shops open directly on the street through one gate to each shop. The goods are displayed in a traditional way on the front façade (Figure 10), this create a comprehensive sensual experience where the users of street can smell various spices, touch several textiles, taste different vegetables and fruits, besides enjoy seeing the colorful goods.

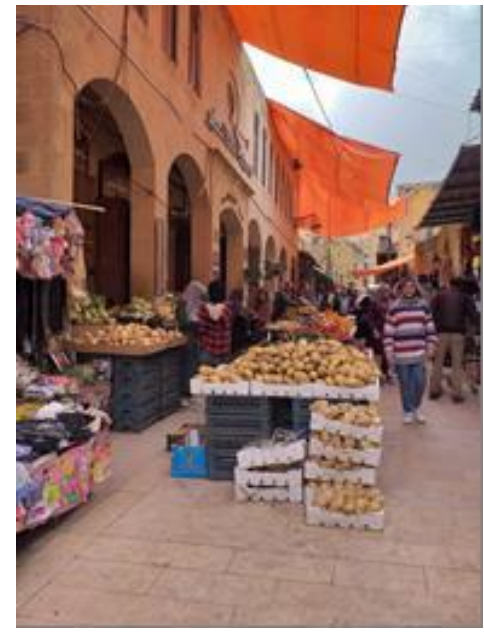

Figure 10. The traditional shops at the Hammam Street. Source: the corresponding author, 2019

Accordingly, to increase the opportunity of accepting the As-salt file at the World Heritage List of the UNESCO, the research suggests studying the public spaces that links the main nominated buildings instead of presenting them as fragmented components. This includes the public squares, the stairs and the open spaces along the Harmony trail. Moreover, studying the user's behavior as they walk along the trail and how they used the urban spaces is essential to design a special system that fulfill their needs. The main activities observed at the public spaces and along the Harmony trail are walking, shopping, sitting for entertainment and playing the traditional games. These activities need well designed public spaces to rest and enjoy, which contributes to the consolidation of social relations.

Furthermore, it is observed by the researchers that there are still some design problems at the public spaces that should be taken into consideration when reviving these spaces for 
example: The smooth white stone that is used in paving some areas collects dust, there are also several hidden stairs in the street which puts pedestrians at risk especially in the winter as well as pooling water in the street to form swamps in different places of the street, likewise, the circulation of the people with special needs is not considered as the hilly topography makes the stairs one of the major connection in the city. Moreover, there are some treatments that are made by locals at the Khader Street to beatify the outdoor spaces such as coloring the planters and the entrances; however, these treatments are neglected and not mentioned in the As-Salt file. The local communities together with the local artists try to draw graffiti arts on walls at the Khader Street but still, these paintings are not professional, and imperfect, unlike those attractive and colorful graffiti arts that are found in the European cities such as those in Brighton/United Kingdom (Figure 11). Therefore, the As-Salt Municipality should benefit from international experiences in reviving and beautifying the public spaces and their components.

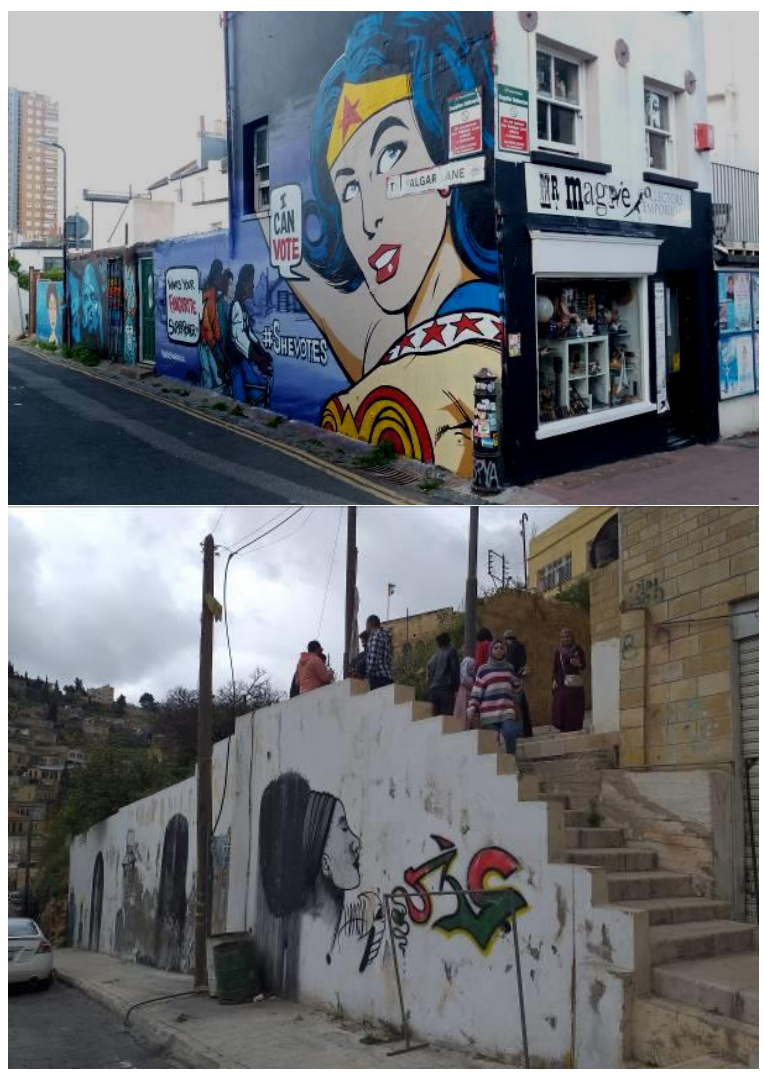

Figure 11. The quality of graffiti arts on walls in Brighton in 2017 (on top) unlike the ones in As-Salt in 2019 (on bottom). Source: the corresponding author

\section{CONCLUSION}

The study confirms that the As-Salt Development Corporation, the As-Salt municipality, as well as the Ministry of Tourism are unaware of the importance of the public spaces such as the Harmony trail, Al-Ain square, Al-Hammam Street and other open spaces in reviving the historical places, refining the urban identity, connecting its fragmented parts, and promoting the city worldwide, thus, increasing the possibility of adding the city to the World Heritage List. As-Salt Development Corporation, the As-Salt municipality, as well as the Ministry of Tourism should benefit from the previous developments of the public spaces and the Harmony trail in 1994, 2004, and 2010. These public spaces should be included it in the UNESCO file to avoid the current shortcomings, and to connect between the fragmented components that are mentioned in the file.

The development of the public space and including them in the As-Salt file is an important step when introducing the ancient city of As-Salt into the World Heritage List instead of presenting only the distinctive architecture of the eight fragmented components. Therefore, the study stressed that the diversity of the heritage and the variety of activity at the city center of the As-Salt city has an important role in making the study area a vibrant urban space, accordingly, this fact should be highlighted in the submitted file.

The Municipality of As-Salt and the other interested parties should focus on the role of the social interaction in the revitalization of public spaces in the city of As-Salt by emphasizing the creation of more attractive pedestrian friendly areas that respects people with special needs and open markets and squares that include events and activities. Moreover, the aesthetic aspects and functional elements of the site should be deeply studied and specified when designing the public spaces, this could be achieved by designing the pathways, paving the surfaces with appropriate stone tiles, studying floor levels and treating them in a manner that facilitates the movement of pedestrians and ensures their safety.

\section{REFERENCES}

[1] Fakhouri, L.A., Haddad, N.A. (2017). Aspects of the architectural and urban heritage: From registers to conservation for adaptive and modern use at the historic cores of salt and Irbid, Jordan. ArchNet-IJAR: International Journal of Architectural Research, 11(2): 190. https://doi.org/10.26687/archnet-ijar.v11i2.1256

[2] Tarrad, M., Al-Omari, O. (2012). The Concept of the Architectural Heritage and Methods of Maintaining it (Case Study: Heritage Buildings in the Governorate of Irbid - Jordan). Proceedings of the $3^{\text {rd }}$ International Architectural Conservation Conference, Dubai Municipality.

[3] Simonds, J.O. (1998). Landscape architecture: A manual of site planning and design New York: The McGraw-Hill Companies, Inc. (No. Sirsi) i9780070577091).

[4] Al-Amed, H. (2002). As-Salt Features of the daily life of the city through the municipal register 1928: Study and investigate. University of Jordan and the Jordanian National Bank. Jordanian Journal of History and Antiquities, 2(2).

[5] Day, C. (2017). Places of the Soul: Architecture and Environmental Design as a Healing Art. Routledge. UK: Elsevier. https://doi.org/10.22269/171128

[6] Khaled, A., Mohamed, G. (1995). Planning Residential neighborhood, Cairo: Anglo Publications.

[7] Gehl, J. (2011). Life Between Buildings: Using Public Space. Island press.

[8] Nouby, H. (2007). Architectural space from modernism to deconstruction: A critical overview. Journal of Engineering Sciences, Assiut University, 35(3): 835-851.

[9] Zalloom, B. (2017). Creating livable public spaces. Official Proceedings of the European Conference on Sustainability, Energy \& the Environment, Brighton.

[10] Habis, M. (2011). Heritage buildings and architectural 
identity of the As-Salt city. The Jordanian Journal of History, 5(1).

[11] Kolonias, S.A. (2014). Charter for the conservation of historic towns and urban areas (Washington 1987). Encyclopedia of Global Archaeology, pp. 1372-1374. https://doi.org/10.1007/978-1-4419-0465-2_1041

[12] Washington Charter (1987). CHARTER FOR THE CONSERVATION OF HISTORIC TOWNS AND URBAN AREAS, available at: https://www.icomos.org/charters/towns_e.pdf, accessed on 20 June, 2019.

[13] Gehl Architects. (2009). Christchurch: Public space Public life, electronic version. https://ccc.govt.nz/assets/Documents/TheRebuild/Strategic-Plans/Christchurch-PSPL-Part1-p173.pdf, accessed on Jun. 1, 2018.

[14] UNESCO. (2016). The town of Salt nominated to become the 6th UNESCO World Heritage Site in Jordan. UNESCO World Heritage Site in Jordan. https://www.select.jo/the-town-of-salt-nominated-tobecome-the-6th-unesco-world-heritage-site-in-jordan, accessed on Dec. 12, 2018.
[15] Al-Qadi, H., Al-Faqeeh, S. (1995). Patterns of urban spaces in the city of As-Salt. Unpublished Master Thesis, Faculty of Graduate Studies, University of Jordan. Dar Al Mandumah. 605574.

[16] Ghneim, O. (2011). The role of topographic factor in shaping the patterns of urban development in the city of As-Salt, Um Al-Qura magazine. Makkah. University of Jordan. Jordanian Journal of History and Antiquities, 5(1).

[17] UNESCO. (2019). The road map for the preparation of a world heritage nominate, Available at: http://www.unesco.org/new/en/amman/about-thisoffice/singleview/news/the_road_map_for_the_preparation_of_a_w orld_heritage_nominat/ [Accessed on 12/12/2018].

[18] Almatarneh, R.T. (2013). Sustainability lessons learnt from traditional architecture: A case study of the old city of As-Salt, Jordan. IOSR Journal of Environmental Science, Toxicology and Food Technology (IOSRJESTFT), 5(3): 107. https://doi.org/10.9790/2402053100109 